\title{
Eesti õpetajate roll laste internetikasutuse sotsiaalses vahendamises
}

\author{
Kadri Soo ${ }^{\text {a1 }}$, Veronika Kalmus ${ }^{\text {, }}$, Mare Ainsaar ${ }^{a}$ \\ a Tartu Ülikooli ühiskonnateaduste instituut
}

\begin{abstract}
Annotatsioon
Õpetajatel on oluline roll laste ettevalmistamisel internetimaailmas toimetulekuks. Artiklis analüüsitakse Eesti õpetajate tegevust 9-16aastaste laste internetikasutuse sotsiaalses vahendamises, mille mõõtmiseks kasutati kaheksat tunnust EU Kids Online'i uuringust. Tulemused näitavad, et enamik Eesti õpetajatest on õpilaste internetikasutust sotsiaalselt vahendanud: üksnes 13\% lastest ei suutnud meenutada, et nad oleks õpetajatelt kunagi juhiseid või informatsiooni saanud. Peamised erinevused Eesti õpetajate tegevuses ilmnesid keele ja asula suuruse puhul. Uuring lubab väita, et eesti keelt rääkivate ja väikestest asulatest pärit laste õpetajad vahendavad laste internetitegevusi aktiivsemalt ja mitmekülgsemalt ning pakuvad internetiohtude korral rohkem nõuandeid. See, kuidas on õpetajate tegevus ja laste kokkupuude internetiohtudega omavahel seotud, erineb vanuseja keelerühmiti. Internetis kahju kogemine ei ole seotud õpetajatepoolse sotsiaalse vahendamisega.
\end{abstract}

Võtmesõnad: internetikasutuse sotsiaalne vahendamine, õpetaja roll, internetiohud, kahju kogemine, digitaalsed oskused

\section{Sissejuhatus}

Tänapäeva ühiskonnas, mida sageli nimetatakse info-, võrgu- või meediaühiskonnaks, on info- ja kommunikatsioonitehnoloogia, eriti internet, saanud paljude laste igapäevaelu lahutamatuks ja enesestmõistetavaks osaks. Üha enam lapsi sünnib infost küllastunud keskkonda, mis erineb oluliselt sellest, kus nende vanemad ja õpetajad üles kasvasid. Seega seisavad lapsi kasvatavad ja õpetavad ning nende heaolu eest vastutavad täiskasvanud silmitsi raskustega, mis erinevad eelnevate põlvkondade ees seisnud

1 Ühiskonnateaduste instituut, sotsiaal- ja haridusteaduskond, Tartu Ülikool, Lossi 36, 51003 Tartu; kadri.soo@ut.ee 
sotsialiseerimisülesannetest (Kalmus, Siibak, \& Blinka, 2014). Sellega seoses tegeldakse haridusvaldkonnas ja teistel aladel järjest enam digitaalse kirjaoskuse küsimustega. On väidetud, et digitaalsed oskused on vajalikud eelkõige koolis (Leu, O’Byrne, Zawilinski, McVerry, \& Everett-Cacopardo, 2009), kuid võib arvata, et tehnoloogiliste vahendite kättesaadavuse edenedes osutuvad need vajalikuks juba enne kooli ja nende arendamine nõuab teistsuguseid pedagoogilisi võtteid, kui on kasutatud traditsioonilise kirjaoskuse õpetamisel (Cope \& Kalantzis, 2000).

Eesti on internetivabaduse poolest maailmas esimese kümne riigi seas (Freedom House, 2014). Eriti aktiivsed infotehnoloogiliste vahendite kasutajad on noored, kellest enamik kasutab internetti peaaegu iga päev (Livingstone, Haddon, Görzig, \& Ólafsson, 2011a). Lapsed ja noored kasutavad internetti peamiselt sõpradega suhtlemiseks, meelelahutuseks ja informatsiooni otsimiseks, kuid ka oma identiteediga eksperimenteerimiseks, romantiliste suhete loomiseks ja seksuaalsuse avastamiseks (Siibak \& Hernwall, 2011; Subrahmanyam \& Greenfield, 2008). Internet pakub ohtralt võimalusi, kuid kätkeb endas ka riske. Ohtlike situatsioonidega kokkupuutumine internetis võib lapsele kaasa tuua emotsionaalse kahju (Davidson et al., 2011; Livingstone \& Smith, 2014; Munro, 2011; Wolak, Mitchell, \& Finkelhor, 2006). Enamasti pöörduvad lapsed sellistes olukordades eakaaslaste poole ja on mõjutatud eakaaslaste hoiakutest (Baumgartner, Valkenburg, \& Peter, 2011), kuid on teada, et täiskasvanutepoolne internetikasutuse sotsiaalne vahendamine - juhendamine, abi ja järelevalve - aitaks lapsel ennetada ohtudega kokkupuutumist või toetada nendega toimetulemist (Dürager \& Livingstone, 2012).

Varasemad uurimused on keskendunud eelkõige lapsevanematepoolsele internetikasutuse sotsiaalsele vahendamisele, esitades tüpoloogiaid ning püüdes hinnata sotsiaalse vahendamise ennetavat või retroaktiivset mõju (Dürager \& Livingstone, 2012; Helweg-Larsen, Schütt, \& Larsen, 2012; Kalmus \& Roosalu, 2012; Livingstone \& Helsper, 2008). Õpetajate tegevust laste meedia-, sh internetikasutuse sotsiaalses vahendamises on uuritud tunduvalt vähem (Kalmus, von Feilitzen, \& Siibak, 2012). Samas näitavad mitmed uurimused (Ainsaar, Soo, Strömpl, Kolpakova, \& Allegro, 2012; O’Connel, Price, \& Barrow, 2004), et peale eakaaslaste ja vanemate ootavad lapsed just ópetajatelt abi interneti turvalisel kasutamisel ja seal peituvate ohtude vältimisel. Kuna Eesti lapsevanemate teadlikkus ja lapse internetikasutuse järelevalve on teiste Euroopa riikidega võrreldes pigem tagasihoidlik (Kalmus, 2013; Livingstone et al., 2011a) ja nad delegeerivad laste internetikasutuse sotsiaalse vahendamise meeleldi teistele sotsialiseerijatele - õpetajatele ja/või lapse vanematele õdedele-vendadele (Komp, 
2012; Vinter \& Siibak, 2012) -, lasub õpetajatel kui täiskasvanud mentoritel tähtis roll lapse internetikasutuse turvalisel juhendamisel.

Analüüsid näitavad, et Eesti õpetajad on laste internetikasutuse sotsiaalse vahendamise aktiivsuselt pisut üle Euroopa keskmise, jagades koos Taani ja Poola kolleegidega 25 riigi seas 9.-11. kohta (Livingstone et al., 2011a). Samas puudub ülevaade Eesti õpetajate tegevusest eri vanuses, keeleruumis ja piirkonnas elavate laste internetikasutuse sotsiaalsel vahendamisel. Samuti napib informatsiooni, milline on õpetajate juhendamistegevuse võimalik mõju laste online-riskide ja kahju kogemisele. Siinse artikli eesmärk on välja selgitada, milliseid sotsiaalse vahendamise viise kasutavad Eesti õpetajad eri vanuses, eri kodukeelega ja eri suuruses asulates elavate laste hinnangul ning kuidas on omavahel seotud õpetajatepoolne vahendamine ning laste kokkupuutumine internetiohtudega ja kahju kogemine.

\section{Teoreetiline ülevaade}

\section{Laste meediakasutuse sotsiaalne vahendamine}

Meediakasutuse sotsiaalse vahendamise mõiste lähtub sotsialiseerimisteooriatest, hõlmates laste ja sotsialiseerijate (sh õpetajate) vahelise sotsiaalse interaktsiooni eri tüüpe, nt juhendamist, selgitamist ja meedia kooskasutamist, samuti reeglite ja piirangute seadmist (Chakroff \& Nathanson, 2011). Tegemist on mitmemõõtmelise, kõrgema üldistustasandi mõistega. Teaduskirjanduses võib kohata kaht võistlevat sotsiaalse vahendamise liigitust: 1) süsteemil ehk tehnilistel lahendustel versus kasutajal ehk juhendamistegevustel põhinev vahendamine; 2) piirav või kaitsev versus juhendav/õpetav või soodustav vahendamine (Kirwil, Garmendia, Garitaonandia, \& Martínez Fernández, 2009).

Konkreetsemal tasandil, laste internetikasutuse vahendamise kontekstis, on esitatud mitmeid vanemliku vahendamise strateegiate tüpoloogiaid, millest on empiirilistes uurimustes enim kasutust leidnud neljane liigitus: 1) aktiivne juhendamine ja kooskasutamine, 2) reeglite ja piirangute seadmine, 3) tehniliste filtrite ja jälgimisprogrammide kasutamine ning 4) meilisõnumite ja külastatavate veebilehtede jälgimine (Livingstone $\&$ Helsper, 2008). Laiemal üldistustasandil, võttes peale vanemate arvesse ka teisi sotsialiseerijaid, võib laste internetikasutuse sotsiaalse vahendamise jagada kahte suurde kategooriasse: ühelt poolt sotsiaalseks toetamiseks, mis hõlmab mitmesuguste sotsialiseerijate (õpetajate, eakaaslaste, vanemate või teiste pereliikmete ja sugulaste) poolset abistamist, juhendamist, kooskasutamist ja -tõlgendamist, ning teiselt poolt reegliteks ja piiranguteks (nii 
sotsiaalseteks kui ka tehnilisteks), mille kehtestavad enamasti õpetajad ja lapsevanemad (Kalmus, 2012).

Tuginedes nii McQuaili (2005) käsitlusele meedia vahendaja-rollidest kui ka laste internetikasutuse sotsiaalset vahendamist puudutavate uurimuste tulemustele, on Kalmus (2012) välja pakkunud sotsialiseerijate vahendaja-rollide tüpoloogia: 1) väravavaht, kes valib laste jaoks välja teatud meediakogemused ja jätab tahtlikult või ebateadlikult kõrvale teised (seda rolli täidavad peamiselt lapsevanemad); 2) treener (ehk teejuht), kes näitab meediamaastikul teed ja aitab aru saada sellest, mis on raskesti mõistetav või millega on raske toime tulla (õpetajate roll treenerina on välja kujunemas); 3) aken, kes avardab laste vaatevälja ja teadmisi meediamaailmast ning selle positiivseid kasutusvõimalusi (selles rollis on valdavalt eakaaslased); 4) nõustaja või usaldusisik, kelle poole lapsed pöörduvad pärast negatiivset internetikogemust (seda retroaktiivset vahendaja-rolli täidavad sagedamini eakaaslased ja lapsevanemad, harvemini ka õpetajad).

Laste meediakasutuse sotsiaalne vahendamine on tihedalt seotud ka meediakasvatuse ja meediakirjaoskuse või meediapädevuse mõistega. Meediakirjaoskus on kompleksne ja mitmetahuline kompetentsus (Bonfadelli, 2007), mis hõlmab võimet kasutada, analüüsida, luua ja edastada meediasõnumeid eri vormis ja kontekstis (Buckingham et al., 2005). Livingstone (2004) lisab nimetatud neljale osaoskusele ka ligipääsu meediasisule ning selle hindamise. Kui ettekavandamata ja süsteemitu, kuid funktsionaalne meediasotsialiseerimine on omane pigem perekondadele (Bonfadelli, 2007), siis kavatsuslikku, eesmärgistatud ning õppekavale toetuvat meediakasvatust meediakirjaoskuse kujundamiseks praktiseeritakse üldjuhul haridusasutustes (Uljens, 1997). Ülalnimetatud sotsiaalse vahendamise strateegiatest on meediakasvatuse pedagoogilise kontseptsiooniga enim seotud aktiivne juhendamine (Vinter, 2013).

\section{Õpetajate roll laste internetikasutuse sotsiaalses vahendamises}

Enamikus varasemates uurimustes (nt Berrier, 2007; Wishart, 2004) ei eristata õpetajatepoolses internetikasutuse sotsiaalses vahendamises strateegiaid ega püüta vastata küsimusele, kuidas õpetajatepoolne vahendamine on seotud laste negatiivsete internetikogemustega. Siiski on mitmes uurimuses käsitletud mõningaid õpetajate tegevuse aspekte, mis mõjutavad laste internetikogemusi.

Seniste uurimuste tulemusi üldistades võib väita, et õpetajad keskenduvad peamiselt internetiturvalisusele, eelistades pigem kehtestada laste internetikasutust piiravaid reegleid kui tegeleda aktiivse juhendamisega. 
Paraku takistab niisugune käitumisviis turvalise internetikasutuse heade tavade kujunemist ja ahendab laste väljavaateid online-võimaluste avastamiseks (Wishart, 2004). Õpetajate toetus avaldab küll nõrka mõju laste sisemisele motivatsioonile internetis tegutsemiseks, kuid see on seotud enamasti konkreetsete õpiülesannete täitmisega (Zhao, Lu, Wang, \& Huang, 2011). Edasijõudnute tasemel tegutsemiseks, nt veebisisu loomiseks, on õpetajatepoolne vahendamine väikseima tähtsusega mõjutegur (Kalmus, Pruulmann-Vengerfeldt, Runnel, \& Siibak, 2009).

EU Kids Online'i küsitlus on üks väheseid, milles uuriti korraga nii lapsevanemate, õpetajate kui ka eakaaslaste sotsiaalse vahendamise praktikat paljudes Euroopa riikides (Livingstone et al., 2011a). Varasemast on teada, et lapsevanemad ootavad sageli, et õpetajad etendaksid laste internetikasutuse toetamisel treeneri või nõustaja rolli, teisisõnu soovitakse, et nad toimiksid in loco parentis ehk vanemate asemel (Wishart, 2004). EU Kids Online'i koguandmestiku analüüs (Kalmus et al., 2012) näitas, et õpetajatepoolne vahendamine on tõepoolest positiivselt seotud õpilaste digitaalsete ja internetiturvalisuse oskustega, mis lubab väita, et õpetajad täidavad Euroopas üldiselt veebiteejuhtide või ka -treenerite rolli. Niisugune seosemuster ei ilmnenud siiski kõigis uuritud 25 riigis, viidates sellele, et õpetajate treeneriroll võib olla alles kujunemisjärgus. Analüüs tõi esile ka nõrga positiivse seose laste negatiivsete online-kogemuste ning õpetajate (ja eakaaslaste) pakutava toetuse vahel. See annab alust arvata, et internetikasutuse sotsiaalne vahendamine võib toimuda retroaktiivselt, kui lapsed pöörduvad õpetajate kui usaldusisikute või lohutajate poole pärast seda, kui nad on kogenud internetis midagi häirivat. EU Kids Online'i Eesti andmetel põhinenud Soo, Ainsaare ja Kalmuse (2012) analüüs ei näidanud aga olulist seost õpetajatepoolse vahendamise ja konkreetse vaadeldud riski, st seksuaalse sisuga sõnumite saamise vahel.

Ainsaare jt (2012) analüüs aitab selgitada, miks lapsed pöörduvad internetiprobleemide puhul õpetajate poole harvemini kui näiteks eakaaslaste poole. Põhjus võib olla selles, et nad ei usalda täiskasvanute internetikompetentsi ning neil võib puududa usk sellesse, et täiskasvanud mõistavad noori. Samuti ei soovi noored, et informatsioon nende tegevuse kohta leviks teiste täiskasvanute seas. Uuring Eesti koolides (Pruulmann-Vengerfeldt, Roots, Strenze, \& Ainsaar, 2015) näitab tõepoolest, et kuigi Eesti õpetajad kasutavad arvutit suhteliselt palju, on nende internetioskuste tase siiski tagasihoidlik.

Hiljuti Eestis tehtud uuringust (TNS Emor, 2014), kus küsitleti 4., 6., 8. ja 12. klasside õpilasi ning nende klassijuhatajaid, ilmnes, et $44 \%$ õpilaste sõnul on õpetaja rääkinud neile õppeaasta jooksul internetis suhtlemisest ja 
sellega seotud ohtudest. Märgitud internetikasutuse vahendamisest teatasid enim lapsed, kes õpivad nooremates klassides (4. ja 6. klassis), kelle kodukeel on eesti keel ning kes elavad maa-asulates. Uuringust ei selgunud, milles täpsemalt seisnes internetisuhtluse juhendamine ning ohtude käsitlemine, samuti mitte õpetajatepoolse vahendamistegevuse võimalik seos ohtude kogemisega. Uuringus küsiti õpetajatelt üksnes küberkiusamisest rääkimise ja nende juhtumitega tegelemise kohta. Internetikiusamisest ja sellega toimetulemisest olid rääkinud peaaegu kõik õpetajad (91\%), neist ligikaudu pooled põhjalikult. Õpetajaid, kelle poole on pöördunud mõni laps internetis toimuva narrimise, mõnitamise või ähvardamise tõttu, oli vähem - 44\% (TNS Emor, 2014).

Opetajate rolli laste internetikasutuse sotsiaalses vahendamises on vaadeldud ka kvalitatiivsetes uurimustes. Raudsiku uurimusest (2012) selgus, et kui õpetaja võtab tunnis jutuks internetiturvalisuse, võib see soodustada samasisulisi vestlusi ka lapse ja lapsevanema vahel. Poolstruktureeritud intervjuud Eesti ja Läti õpetajatega (Karaseva, Siibak, \& Pruulmann-Vengerfeldt, 2015) näitasid, et õpetajad täidavad enamasti kas õpilaste internetikasutust suunavate-piiravate väravavahtide või juhendavate teejuhtide/treenerite rolli (vrd Kalmus, 2012). Need kaks rolli ei ole üksteist välistavad, vaid neid etendatakse integreeritult, olenevalt ópetaja arusaamast selle kohta, mis aitab konkreetses situatsioonis parimal viisil saavutada õpieesmärki ning sobib õpilaste ja õpetaja vajadustega. Vähesed õpetajad täitsid õpilaste internetikasutuses uusi võimalusi avavate akende rolli. Karaseva ja tema kolleegide uuringu valimi põhjal (27 osalejat) ei tulnud aga ilmsiks õpetajate kui usaldusisikute või lohutajate roll.

\section{Internetiohud ja kahju kogemine}

Ohud, millega lapsed võivad kübermaailmas kokku puutuda, varieeruvad isikuandmete kuritarvitamisest ja eakaaslaste omavahelisest küberkiusamisest kuni pornograafilise materjali nägemise ja seksuaalse ärakasutamiseni (Hasebrink, Livingstone, \& Haddon, 2008). Online-keskkonna näiline anonüümsus ja turvalisus ajendavad lapsi ja noori tegema internetis asju, mida nad reaalses elus nii kindlalt ei teeks. Virtuaalkeskkond hõlbustab noortel võõrastega suhtlemist, tutvuste loomist, pahatahtlike või kedagi solvavate sõnumite saatmist, identiteediga eksperimenteerimist, aga ka seksuaalsust puudutava info otsimist ja seksiga seotud teemadel vestlemist (Kanuga \& Rosenfeld, 2004; Siibak \& Hernwall, 2011). Arvutis suhtlemine tekitab tunde, et ohtude eest ollakse kindlamalt kaitstud kui reaalses elus. 
Isiklike andmete avaldamine, endast paljastavate piltide üleslaadimine ja võõrastega tutvumine võivad äratada ebatervet huvi ja viia soovimatu (seksuaalse) tähelepanuni (Mitchell, Finkelhor, \& Wolak, 2007). Internetis tutvutud inimesega päriselus kohtumine võib täiskasvanute, eelkõige õiguskaitseametnike arvates suurendada laste seksuaalse ärakasutamise tõenäosust (Wolak, Finkelhor, Mitchell, \& Ybarra, 2008; Wolak, Mitchell, \& Finkelhor, 2003). Lapsed ise peavad internetis võõrastega suhtlemist põnevaks ja mänguliseks (Berson, 2003; Valkenburg \& Peter, 2007) ning paljud neist ei nimeta internetikeskkonnas ette tulnud riskantseid olukordi enda heaolu kahjustavaks (De Graaf \& Vanwesenbeeck, 2006; Livingstone \& Bober, 2004; Quayle, Hutton, \& McKenzie, 2012). Samas on kolmandik seksuaalse sisuga sõnumeid saanud Eesti lastest ning pool internetis pornograafilise materjaliga kokkupuutunutest tundnud end juhtunust häirituna (Livingstone et al., 2011a).

Internetiohte kogevad enim teismeeas lapsed, kes kasutavad internetti sagedamini, riskantselt ning kelle digitaalsed oskused on keskmisest paremad (Helweg-Larsen et al., 2012; Soo et al., 2012; Staksrud, Ólafsson, \& Livingstone, 2013). Uurimistulemused näitavad, et rohkem saavad seksuaalse sisuga sõnumeid ja on küberkiusamise sihtmärgiks noored, kes suhtlevad sageli jututubades, MSNis või teistes suhtlusvõrgustikes, ning eriti need, kes suhtlevad võõrastega või räägivad seksuaalsetel teemadel (Baumgartner, Valkenburg, \& Peter, 2010; De Graaf \& Vanwesenbeeck, 2006; Mitchell, Finkelhor, \& Wolak, 2001; Mitchell et al., 2007). Internetis kalduvad sagedamini võõrastega lähedasi suhteid looma ning nendega päriselus kohtuma noored, kes on vähem rahul oma eluga, tunnevad end eakaaslaste poolt kiusatuna ja on võõrandunud oma vanematest (Livingstone \& Helsper, 2007; Wolak et al., 2003).

\section{Hüpoteesid}

Artiklis uurime, milliseid sotsiaalse vahendamise meetodeid kasutavad laste hinnangul Eesti õpetajad ning kuidas see erineb laste demograafiliste tunnuste lõikes. Lisaks analüüsime, kuidas on õpetajatepoolne internetikasutuse sotsiaalne vahendamine ning laste kokkupuutumine internetiohtudega ja kahju kogemine omavahel seotud. Täpsemalt vaatleme, kas ja kuivõrd ennustab õpetajatepoolne vahendamistegevus, laste internetikasutuse aktiivsus ja kompetentsus laste kokkupuudet nelja internetiohuga (küberkiusamine, internetituttavaga silmast silma kohtumine, pornograafilise materjali nägemine ning seksuaalse sisuga sõnumite saamine), võttes arvesse laste vanust, asulatüüpi ja kodukeelt. 
Töös püstitame järgmised hüpoteesid:

1) tuginedes varasematele uuringutele Eestis (Soo et al., 2012; TNS Emor, 2014), eeldame, et õpetajatepoolne internetikasutuse sotsiaalne vahendamine oleneb lapse demograafilisest taustast: oletame, et väiksematest asulatest pärit ja eesti keelt kõnelevate laste hinnangul juhendavad õpetajad õpilasi rohkem kui suuremates asulates elavate ning vene keelt rääkivate laste hinnangul;

2) pidades silmas retroaktiivse juhendamise hüpoteesi (Kalmus et al., 2012), eeldame, et õpetajatepoolne internetikasutuse vahendamine ning lapse kokkupuutumine internetiohtudega ja internetis kahju kogemine on omavahel positiivselt seotud.

\section{Metoodika}

\section{Protseduur ja valim}

Artiklis kasutame esindusliku uuringu EU Kids Online andmestikku. Uuringus küsitleti 9-16aastaseid internetikasutajaid ja üht nende vanematest 25 Euroopa riigis $(N=25142)$. Tegemist on mastaapseima ja põhjalikema Euroopa laste internetikasutust ja -turvalisust käsitleva uuringuga, mida rahastas Euroopa Komisjon ning mille ettevalmistamises osales üle saja teadlase rahvusvahelisest uurimisvõrgustikust EU Kids Online prof Sonia Livingstone'i (London School of Economics and Political Science) juhtimisel. Küsitlusankeet tõlgiti inglise keelest 24 keelde ja seejärel tõlke adekvaatsuse kontrollimiseks tagasi inglise keelde ning see läbis nii kognitiivse kontrolli kui väikesevalimilise prooviuuringu kõigis osalenud riikides. Paljudele küsimustele lisati riigiomased näited ja kultuurispetsiifilised terminid. Silmast silma intervjuud toimusid laste kodudes; delikaatsete küsimuste jaoks kasutati isetäidetavat ankeeti. (Metodoloogia põhjalikku kirjeldust vt Livingstone, Haddon, Görzig, \& Ólafsson, 2011b.)

Artiklis kasutame Eesti laste andmestikku $(N=1005)$. Eestis koguti andmeid 2010. aasta maist juulini (andmekoguja AS Turu-uuringud). Uuritavad pered leiti üle Eesti 137 valimipunktis juhuaadressi meetodil. Vastamise määr oli 78\%. Intervjuud toimusid CAPI-meetodil (intervjueerija sisestas vastused arvutisse); lapse ja lapsevanema intervjuu kogupikkus oli keskmiselt 68 minutit. Sooliselt jagunes Eesti laste valim võrdselt. Neli viiendikku uuritavatest (81\%) rääkis kodus eesti keelt (sh $1 \%$ nii eesti kui ka vene keelt), ligi viiendik kõneles aga vene keelt. Vastajate keskmine vanus oli $12,7(S D=2,33)$. Ülevaade uuritavate demograafilisest jaotusest on esitatud tabelis 1 . 
Tabel 1. Vastajate demograafiline taust (\%)

\begin{tabular}{l|c}
\hline Tunnus & Osakaal \\
\hline Sugu & \\
$\quad$ Poisid & 50,6 \\
$\quad$ Tüdrukud & 49,4 \\
\hline Vanuserühm & \\
$9-10$ & 22,0 \\
$11-12$ & 23,1 \\
$13-14$ & 26,4 \\
$15-16$ & 28,5 \\
\hline Kodukeel & \\
Eesti keel & 81,4 \\
Vene keel & 18,6 \\
\hline Asula suurus & \\
$\quad$ Väike (kuni 10000 elanikku) & 46,4 \\
Keskmine (10 001 - 100 000 elanikku) & 29,0 \\
Suur (üle 100 000 elaniku) & 24,6 \\
\hline
\end{tabular}

\section{Analïïsis kasutatud tunnused}

Opetajatepoolne internetikasutuse sotsiaalne vahendamine

Õpilastelt küsiti jah-ei skaalal tabelis 2 esitatud kaheksa tegevuse kohta, kas keegi nende kooli õpetajatest on neid kunagi teinud. Kaheksa tunnuse põhjal moodustasime dihhotoomse tunnuse $(0$ - õpetajad ei ole lapsi ühelgi viisil juhendanud, 1 - õpetajad on juhendanud lapsi vähemalt ühel loetletud viisil) ning jaatavate vastuste summeerimise teel vahendamise indeksi. Indeksi väärtused jäid vahemikku 0-8 (suurem väärtus tähendab enamate vahendamismeetodite kasutamist).

\section{Internetiohtudega kokkupuutumine}

Uuringus küsiti 11-16aastastelt lastelt, milliste nelja tüüpi internetiohtudega on nad küsitlusele eelnenud 12 kuu jooksul kokku puutunud: 1) internetis seksuaalse sisuga sõnumite (sõnade, piltide või videote) saamine või nägemine, 2) vastaja suhtes solvavalt või vastikult käitumine internetis (küberkiusamine), 3) pornograafilise materjali nägemine internetis ja 4) silmast silma kohtumine inimesega, kellega kõigepealt tutvuti internetis. Et hinnata ohtudega kokkupuutumist, moodustasime indeksi jaatavate vastuste summeerimise teel. Indeksi skaala varieerus 0st (ei ole puutunud 
kokku ühegi ohtliku situatsiooniga) 4ni (on puutunud kokku kõigi situatsioonidega).

\section{Internetis kahju kogemine}

Viimase 12 kuu jooksul internetiohtudega kokkupuutunud lastelt küsiti, kas nad on tundnud end häirituna (st tundnud end ebamugavalt, läinud endast välja või tundnud, et ei oleks pidanud situatsiooniga kokku puutuma) järgmistel põhjustel: 1) internetis seksuaalse sisuga sõnumite saamine või nägemine, 2) pornograafilise materjali nägemine ja 3) internetis kohatud inimesega silmast silma kohtumine. Internetis kahju kogemise mõõtmiseks moodustasime dihhotoomse tunnuse: 1 - vastaja ei ole kokku puutunud ühegi ohtliku situatsiooniga või kogenud kahju, 2 - vastaja on kogenud kahju, mis tuleneb vähemalt ühest ohust. Küberkiusamisest tingitud kahju kogemine on analüüsist välja jäetud, kuna seda mõõdeti teise skaalaga.

\section{Digitaalsed oskused}

11-16aastastel lastel paluti hinnata jah-ei skaalal, mida nad oskavad veebis teha. Valikusse kuulus kaheksa tegevust: erinevate veebilehtede võrdlemine eesmärgiga otsustada, kas info vastab tõele, filtrite pealepanemine ja vahetamine, veebilehe lisamine järjehoidjasse; soovimatu reklaami/ rämpsmeilide/spämmi blokeerimine, oma surfamise ajaloo kustutamine, privaatsussätete muutmine suhtlusportaali profiilis, soovimatu isiku sõnumite blokeerimine, interneti turvalise kasutuse kohta info leidmine. Jaatavate vastuste liitmise teel saime indeksi (skaala $0-8$ ), mis peegeldab internetikasutuse kompetentsust.

\section{Internetitegevuste mitmekesisus}

11aastastelt ja vanematelt vastajatelt küsiti, mis tegevusi 16st (nt MSNi kasutamine, meilide saatmine/saamine, veebikaamera kasutamine) olid nad internetis harrastanud ning kui sageli olid nad seda teinud viimase kuu aja jooksul (1 - iga päev või peaaegu iga päev, 2 - korra või paar nädalas, 3 korra või paar kuus). Järgnevalt liitsime tegevust vähemalt korra nädalas (esimene või teine skaalapunkt) harrastanud laste vastused kokku, saades tunnuse, mille väärtused jäävad vahemikku $0-16$. Väärtus 0 tähendab, et laps ei olnud ühtegi nimetatud tegevust harrastanud või oli harrastanud neid harvem kui kord nädalas. Mida suurem on indeksi väärtus, seda enam harrastas laps loetletud internetitegevusi iga nädal. 


\section{Andmeanalüïsi meetodid}

Andmeid analüüsisime statistikapaketiga SPSS 20.0. Demograafiliste rühmade (soo, vanuse, kodukeele, asulatüübi) erinevuste väljaselgitamiseks õpetajatepoolse internetikasutuse sotsiaalse vahendamise viiside puhul kasutasime $\chi^{2}$-analüüsi, indeksi puhul aga dispersioonanalüüsi (ANOVA) ning $t$-testi. Regressioonanalüüsi abil prognoosisime internetiohtudega kokkupuutumist ja kahju kogemist, võttes mudelisse sõltumatute tunnustena õpetajatepoolse internetikasutuse sotsiaalse vahendamise, digitaalsed oskused, internetitegevuste mitmekesisuse ning demograafilised näitajad. Kuna internetiohtudega kokkupuutumise indeks on arvtunnus, siis rakendasime selle ennustamisel lineaarset regressioonanalüüsi vähimruutude meetodil ja kahju kogemise kui nominaaltunnuse puhul binaarset logistilist regressioonanalüüsi. Argumenttunnuste vahel multikollineaarsust ei esinenud. Seda tõestas üsna suur tolerantsikordaja, mis varieerus 0,62 st digitaalsete oskuste puhul kuni 0,94 ni õpetajatepoolse internetikasutuse vahendamise puhul.

\section{Tulemused}

\section{Õpetajatepoolse internetikasutuse sotsiaalse vahendamise praktika õpilaste hinnangul}

Enamik Eesti 9-16aastastest õpilastest (87\%) märkis, et õpetajad olid vähemalt ühte internetikasutuse sotsiaalse vahendamise viisi koolis rakendanud. Tabelis 2 esitame õpetajatepoolse vahendamise viisid Livingstone' $i$ ja tema kolleegide (2011a) liigituse järgi. Enim olid õpetajad kehtestanud internetikasutuse piiranguid ning aidanud teha internetis keerukaid asju või sealt midagi leida (60-65\%). Kõige vähem olid õpetajad abistanud või nõustanud lapsi, kui neid midagi internetis häiris.

Poiste ja tüdrukute hinnangud õpetajatepoolsele internetikasutuse vahendamisele erinesid statistiliselt oluliselt ainult kahe viisi puhul. Võrreldes poistega olid õpetajad aidanud tüdrukutel rohkem teha internetis midagi keerukat või sealt midagi leida ning jaganud soovitusi, kui miski lapsi internetis häiris. Eesti kodukeelega ja väikestest asulatest pärit lapsed nimetasid teiste rühmadega võrreldes märksa enam kõiki piirava ja internetiturvalisusega seotud aktiivse vahendamise tegevusi. Eriti suured erinevused ilmnesid tegevustes, mille puhul pidid õpetajad ópetama keerukate asjade tegemist internetis, selgitama heade ja halbade veebilehtede olemust ning juhendama internetis teiste inimestega suhtlemist. 
Tabel 2. Õpetajatepoolse internetikasutuse vahendamise viisid soo, kodukeele ja asulatüübi järgi (\%)

\begin{tabular}{|c|c|c|c|c|c|c|c|c|}
\hline & \multirow[b]{2}{*}{$\begin{array}{c}\text { Kogu- } \\
\text { valim }\end{array}$} & \multicolumn{2}{|c|}{ Sugu } & \multicolumn{2}{|c|}{ Kodukeel } & \multicolumn{3}{|c|}{ Asulatüüp } \\
\hline & & Poiss & Tüdruk & Eesti & Vene & Väike & $\begin{array}{l}\text { Kesk- } \\
\text { mine }\end{array}$ & Suur \\
\hline \multicolumn{9}{|l|}{ Piirav vahendamine } \\
\hline $\begin{array}{l}\text { Kehtestanud reegleid, } \\
\text { mida sa võid koolis } \\
\text { internetis teha }\end{array}$ & 65 & 66 & 64 & $67^{*}$ & 54 & $72 *$ & 57 & 60 \\
\hline \multicolumn{9}{|c|}{ Internetikasutuse aktiivne vahendamine } \\
\hline $\begin{array}{l}\text { Rääkinud sinuga sellest, } \\
\text { mida sa internetis teed }\end{array}$ & 35 & 33 & 37 & 35 & 33 & 35 & 32 & 36 \\
\hline \multicolumn{9}{|c|}{ Internetiturvalisusega seotud aktiivne vahendamine } \\
\hline $\begin{array}{l}\text { Aidanud sind, kui } \\
\text { internetis on vaja midagi } \\
\text { keerukat teha või sealt } \\
\text { midagi leida }\end{array}$ & 60 & $54^{*}$ & 65 & $63 *$ & 44 & $69 *$ & 56 & 46 \\
\hline $\begin{array}{l}\text { Rääkinud, miks mõned } \\
\text { veebilehed on head või } \\
\text { halvad }\end{array}$ & 54 & 55 & 54 & $57^{*}$ & 40 & $63^{*}$ & 48 & 45 \\
\hline $\begin{array}{l}\text { Soovitanud sulle, kuidas } \\
\text { internetti turvaliselt } \\
\text { kasutada }\end{array}$ & 53 & 53 & 54 & $55^{*}$ & 44 & $61 *$ & 46 & 48 \\
\hline $\begin{array}{l}\text { Andnud nõu, kuidas teiste } \\
\text { inimestega internetis } \\
\text { käituda }\end{array}$ & 41 & 42 & 39 & $44^{*}$ & 27 & $48 *$ & 32 & 38 \\
\hline $\begin{array}{l}\text { Rääkinud sulle sellest, } \\
\text { mida teha, kui teatud asi } \\
\text { sind internetis häirib }\end{array}$ & 35 & $31 *$ & 38 & $36^{*}$ & 26 & $40^{*}$ & 29 & 30 \\
\hline $\begin{array}{l}\text { Aidanud sind, kui teatud } \\
\text { asi sind internetis häiris või } \\
\text { tekitas muret }\end{array}$ & 24 & 24 & 23 & $25^{*}$ & 17 & $31 *$ & 14 & 20 \\
\hline
\end{tabular}

Märkused. Tabelis on kasutatud Livingstone'i jt (2011a) sotsiaalse vahendamise tüpoloogiat. Tärniga tähistatud osakaalud erinevad statistiliselt oluliselt $(p<0,05)$ vaadeldud rühmade arvestuses $x^{2}$-statistiku alusel. 
Tabelis 3 on esitatud andmed selle kohta, kui paljud lapsed on teatanud vähemalt ühest õpetajatepoolse interneti sotsiaalse vahendamise viisist, ning toodud vahendamise indeksi keskmised väärtused rühmade kaupa. Poiste ja tüdrukute hinnangud õpetajatepoolse internetikasutuse vahendamise praktikale ei erinenud. Samas erines internetikasutuse vahendamise indeks statistiliselt oluliselt kodukeele, vanuse ja asulatüübi lõikes. Täpsemalt nimetasid eesti keelt rääkivad, vanematesse vanuserühmadesse kuuluvad ja väikestes asulates elavad lapsed märgatavalt rohkem erinevaid õpetaja kasutatud vahendamisviise kui vene keelt kõnelevad, nooremad ning keskmistes ja suurtes asulates elavad lapsed.

Tabel 3. Õpetajatepoolse internetikasutuse vahendamine laste demograafiliste näitajate järgi

\begin{tabular}{l|c|c|c|c}
\hline & Vähemalt ühe vahenda- & \multicolumn{3}{|c}{ Vahendamise indeks } \\
\cline { 3 - 5 } & misviisi kasutamine \% & $M$ & $S D$ & $t / F$ \\
\hline Sugu & & & & \\
Poisid $(N=504)$ & 87 & 3,5 & 2,5 & $-1,12$ \\
Tüdrukud $(N=493)$ & 87 & 3,7 & 2,5 & \\
\hline Kodukeel & & & & \\
Eesti keel $(N=813)$ & 89 & 3,7 & 2,4 & $4,81^{* * *}$ \\
Vene keel $(N=182)$ & 78 & 2,8 & 2,5 & \\
\hline Vanus & & & & \\
9-10 $(N=220)$ & 78 & 2,9 & 2,6 & $8,1^{* * *}$ \\
$11-12(N=230)$ & 88 & 3,6 & 2,4 & \\
$13-14(N=263)$ & 90 & 3,7 & 2,4 & \\
$15-16(N=285)$ & 91 & 4,0 & 2,5 & \\
\hline Asula suurus & & & & \\
Väike $(N=464)$ & 92 & 4,1 & 2,5 & $22,8^{* * *}$ \\
Keskmine $(N=288)$ & 83 & 3,1 & 2,4 & \\
Suur $(N=245)$ & 84 & 3,1 & 2,3 & \\
\hline
\end{tabular}

Märkused. Rühmadevahelisi erinevusi on kontrollitud dispersioonanalüüsi $(F)$ ja t-testiga. $M=$ keskmine tulemus; $S D=$ standardhälve. ${ }^{* * *} p<0,001$. 


\section{Internetiohtudega kokkupuutumine ja kahju kogemine}

Küsitlusele eelnenud 12 kuu jooksul oli 47\% 11-16aastastest lastest puutunud kokku vähemalt ühe uuringus käsitletud internetiohu liigiga. Ligikaudu neljandik oli kogenud ainult ühte liiki ohtu, 13\% kahte ning iga kümnes kolme või nelja liiki ohtu. Ohtude kogemise indeksi keskmine väärtus oli $0,83(S D=1,10)$. Suurem osa lastest $(83 \%)$, kes olid ohte kogenud, ei tundnud end neist häirituna.

Järgnevalt analüüsime, kuidas ennustab õpetajatepoolse internetikasutuse sotsiaalne vahendamine koos laste internetitegevuste mitmekesisuse, digitaalsete oskuste ja demograafiliste näitajatega 11-16aastaste laste kokkupuutumist internetiohtudega ning neist häirituna tundmist. Tabelis 4 on esitatud kaheksa lineaarset regressioonmudelit, millest esimesse on kaasatud kogu valim, ülejäänutesse aga lapsed vanuse, kodukeele ja asulatüübi järgi. Tulemustest ilmneb statistiliselt oluline positiivne seos sõltuva tunnuse ning vanuse, digitaalsete oskuste ja laste internetitegevuste mitmekesisuse vahel peaaegu kõigi mudelite puhul. Seega on vanematel, internetikasutuses kompetentsematel ja virtuaalkeskkonnas erinevaid tegevusi harrastavatel lastel suurem tõenäosus puutuda kokku internetiohtudega. Õpetajatepoolne internetikasutuse vahendamine on oluliselt seotud internetiohtude kogemisega 14-16aastaste, eesti keelt rääkivate ja väikestest asulatest pärit laste mudelite puhul. Olulisusenivool $p<0,1$ võib öelda, et suurem sotsiaalne vahendamine on positiivselt seotud suurtes asulates elavate laste internetiohtude kogemise riskiga, seevastu vene keelt kõnelevate laste puhul on seos negatiivne - lapsed, kellele õpetajad on internetiga seotud küsimusi enam vahendanud, puutuvad ohtudega vähem kokku. Demograafilistest tunnustest ennustab riskide kogemist 14-16aastaste laste mudelis asula suurus. 
Tabel 4. Lineaarsed regressioonmudelid (standardiseeritud regressioonikordajad), mis prognoosivad 11-16aastaste laste kokkupuutumist internetiohtudega

\begin{tabular}{|c|c|c|c|c|c|c|c|c|}
\hline \multirow[b]{2}{*}{$\begin{array}{l}\text { Sõltumatud } \\
\text { tunnused }\end{array}$} & \multirow[b]{2}{*}{$\begin{array}{l}\text { Kogu- } \\
\text { valim }\end{array}$} & \multicolumn{2}{|c|}{ Vanus } & \multicolumn{2}{|c|}{ Kodukeel } & \multicolumn{3}{|c|}{ Asula suurus } \\
\hline & & $11-13$ & $14-16$ & Eesti & Vene & Väike & $\begin{array}{l}\text { Kesk- } \\
\text { mine }\end{array}$ & Suur \\
\hline $\begin{array}{l}\text { Õpetajate- } \\
\text { poolne } \\
\text { interneti- } \\
\text { kasutuse } \\
\text { vahendamine }\end{array}$ & 0,05 & $-0,05$ & $0,12^{*}$ & $0,10^{* *}$ & $-0,14^{\dagger}$ & $0,10^{*}$ & $-0,05$ & $0,13^{\dagger}$ \\
\hline $\begin{array}{l}\text { Digitaalsed } \\
\text { oskused }\end{array}$ & $0,15^{* * *}$ & $0,15^{* *}$ & $0,19^{* * *}$ & $0,13^{* *}$ & $0,21^{*}$ & $0,13^{*}$ & $0,24^{* *}$ & 0,10 \\
\hline $\begin{array}{l}\text { Interneti- } \\
\text { tegevuste } \\
\text { mitmekesisus }\end{array}$ & $0,21^{* * *}$ & $0,30 * * *$ & $0,19^{* * *}$ & $0,22^{* * *}$ & $0,18^{\dagger}$ & $0,24^{* * *}$ & $0,16^{*}$ & $0,26^{* *}$ \\
\hline Sugu & $0,067^{\dagger}$ & 0,05 & 0,08 & $0,06^{\dagger}$ & 0,05 & 0,01 & 0,06 & $0,12^{\dagger}$ \\
\hline Vanus & $0,17^{* * *}$ & - & - & $0,16^{* * *}$ & $0,21^{*}$ & $0,12^{*}$ & $0,17^{*}$ & $0,22^{* *}$ \\
\hline Kodukeel & 0,06 & $-0,09$ & $-0,04$ & - & - & 0,00 & 0,05 & 0,09 \\
\hline Asula suurus & $0,06^{\dagger}$ & $-0,02$ & $0,11^{*}$ & $0,07^{\dagger}$ & $-0,01$ & - & - & - \\
\hline $\mathrm{R}^{2}$ & 0,19 & 0,16 & 0,13 & 0,19 & 0,23 & 0,17 & 0,21 & 0,24 \\
\hline$F(d f)$ & $\begin{array}{c}26,15 \\
(775)^{* * * *}\end{array}$ & $\begin{array}{c}11,08 \\
(354)^{* * *}\end{array}$ & $\begin{array}{c}10,60 \\
(420)^{* * *}\end{array}$ & $\begin{array}{c}24,29 \\
(638)^{* * * *}\end{array}$ & $\begin{array}{c}6,35 \\
(136)^{* * * *}\end{array}$ & $\begin{array}{c}12,18 \\
(362)^{* * *}\end{array}$ & $\begin{array}{c}9,98 \\
(228)^{* * * *}\end{array}$ & $\begin{array}{c}9,36 \\
(183)^{* * * *}\end{array}$ \\
\hline
\end{tabular}

Märkused. $d f$-vabadusastmete arv. ${ }^{\dagger} p<0,1 ;{ }^{*} p<0,05 ;{ }^{* *} p<0,01 ;{ }^{* * *} p<0,001$.

Tabel 5 kajastab internetis kahju kogemist ennustava logistilise regressioonmudeli tulemusi. Kuna internetiohtudest tingitud kahju koges väike arv lapsi, siis ei ole usaldusväärne teha eraldi analüüsi demograafiliste rühmade kaupa. Sama moodi nagu ohtudega kokkupuutumisel, on ka praegusel juhul suurem tõenäosus tunda end ohtudest häirituna paremate digitaalsete oskustega ning internetti mitmekesiselt kasutavatel lastel kui neil, kes hindasid oma digitaalseid oskusi tagasihoidlikumaks ning internetitegevuste arvu väiksemaks. Emotsionaalset kahju kogevad enam ka tüdrukud ning vene keelt kõnelevad lapsed. Õpetajatepoolne internetikasutuse sotsiaalne vahendamine ei ole kahju kogemisega statistiliselt oluliselt seotud. 
Tabel 5. Logistilise regressiooni mudel (regressioonikordaja, riskisuhe), mis prognoosib 11-16aastaste laste kahju kogemist internetis

\begin{tabular}{l|c|c}
\hline Sõltumatud tunnused & Kordaja & Riskisuhe \\
\hline Õpetajatepoolne internetikasutuse vahendamine & 0,03 & 1,03 \\
Digitaalsed oskused & 0,14 & $1,15^{*}$ \\
Internetitegevuste mitmekesisus & 0,13 & $1,14^{* *}$ \\
\hline Sugu & & \\
$\quad$ Poisid & $-0,47$ & $0,63^{*}$ \\
$\quad$ Tüdrukud & 0,12 & 1 \\
\hline Vanus & & $1,13^{\dagger}$ \\
\hline Kodukeel & $-0,62$ & $0,54^{*}$ \\
$\quad$ Eesti keel & & 1 \\
$\quad$ Vene keel & & \\
\hline Asula suurus & $-0,41$ & 0,67 \\
$\quad$ Väike & 0,01 & 1,01 \\
$\quad$ Keskmine & & 1 \\
$\quad$ Suur & 0,13 & \\
\hline Nagelkerke $R^{2}$ & 771 & \\
$X^{2}(d f)$ & $57(8)^{* * *}$ & \\
$N$ & & \\
\hline
\end{tabular}

Märkus. ${ }^{\dagger} p<0,1 ;{ }^{*} p<0,05 ;{ }^{* *} p<0,01 ; * * * 0,001$.

\section{Arutelu}

Artiklis uurisime Eesti laste hinnanguid õpetajatepoolsele internetikasutuse sotsiaalsele vahendamisele ning nende seoseid internetiohtudega kokkupuutumise ja emotsionaalse kahju kogemisega. Tulemused näitasid, et suure osa õpilaste (87\%) arvates oli õpetaja vähemalt ühel viisil nende internetikasutust juhendanud. Õpetajatepoolseid vahendamisstrateegiaid lähemalt uurides võis eristada rolle, mida õpetajad erineval määral praktiseerisid. Enim olid õpetajad rakendanud piiravat vahendamist, kehtestades koolis reegleid internetitegevusele ja piirates juurdepääsu (sobimatutele) veebilehtedele, täites seega Kalmuse (2012) tüpoloogia järgi väravavahi rolli. Teisele kohale asetus internetiturvalisust puudutav aktiivne vahendustegevus, mis jagunes konkreetsete vahendamisviiside sageduse poolest kaheks. Rohkem mainiti veebikeskkonnas keerukate ülesannetega toimetuleku õpetamist ning internetis turvalise käitumise juhiste andmist, mis kuuluvad treeneri rolli juurde (vt Kalmus, 2012). 
Oluliselt vähem nimetasid lapsed õpetajate nõustaja või usaldusisiku funktsiooni. See on kooskõlas varasemate uuringute tulemustega (Kalmus et al., 2012; Karaseva et al., 2015). Siit järeldub, et Eesti lastel ei ole negatiivsete internetikogemuste korral eriti kombeks pöörduda õpetaja poole abi ja nõu saamiseks või nad ei pea õpetajaid sellises olukorras potentsiaalseteks toetajateks. Kõnealune vahendamisviis eeldab pedagoogilt üldisi teadmisi nõustamise põhimõtetest, valmisolekut sekkuda olukorda lapse isikliku probleemi korral ning usalduslikku suhet lapsega. Meie uuringust paraku ei selgunud, milliseid muresid ja häirivaid olukordi pidasid lapsed silmas, kui nad küsimustikku täites märkisid, et õpetaja on neid sellisel puhul aidanud. Selge on aga see, et mida tundlikuma teemaga on lapse probleem seotud (nt seksuaalse sisuga sõnumite saamine internetis), seda keerukam ja rohkemaid teadmisi nõudev on sekkumine õpetaja jaoks.

Õpetajate vahendamisstrateegiaid võib kirjeldada ka kollektiivse-personaalse tegevuse skaalal. Kollektiivile suunatud vahendamistegevuse näidete hulka kuuluvad internetikasutuse reeglite kehtestamine ning teavitustöö internetiturvalisuse alal. Personaalne sekkumine hõlmab tegelemist konkreetse lapse internetikasutuse probleemidega, veebisisu analüüsimist ja selgitamist, abistamist murede ja ebameeldivate juhtumite puhul. Uurimistulemuste analüüsist selgus, et peamiselt kogu klassile suunatud vahendamistehnikaid kasutavad õpetajad laste hinnangul oluliselt rohkem kui individuaalset sekkumist eeldavaid tegevusi. Kui õpetajatepoolne kollektiivne vahendamine võib olla osa õppetööst, siis individuaalne sekkumine on sageli koolitunniväline, nõudes õpetajalt lisaaega ja pühendumist. Selline tegevus kuulub nõustaja rolli juurde, seades õpetajale uusi ülesandeid.

Analüüsides laste hinnanguid õpetajatepoolsele internetikasutuse vahendamisele demograafiliste tunnuste järgi, näitasime, et kõige enam juhendatakse väikestes asulates elavaid ja eesti kodukeelega (tõenäoliselt ka eesti õppekeelega) lapsi. Tulemused kinnitavad meie esimest hüpoteesi ning on kooskõlas varasemate Eesti uuringute leidudega (Soo et al., 2012; TNS Emor, 2014). Vahendamisviiside analüüsist ilmnes, et eri kodukeelega ja eri asulatüüpidest pärit laste hinnangud õpetajatepoolsele internetikasutuse aktiivsele vahendamisele ei erine, küll aga lahknesid nende vastused kõigi teiste vahendamisstrateegiate korral. Suurim erinevus eesti- ja venekeelsete laste vahel oli see, et eesti keelt kodukeelena kõnelevad lapsed nimetasid enam õpetaja treeneri rolli hulka kuuluvaid tegevusi (sh nõuanded interneti ohutuks kasutamiseks, hea ja halva veebisisu selgitamine). Eesti keelt kõnelevatele lastele seati ka enam internetikasutuse piiranguid ning neid abistati internetiga seotud isiklike probleemide korral, kuid need erinevused keelerühmade vahel ei olnud väga suured. 
Väikeste asulate lapsed nimetasid teistest asulatüüpidest pärit õpilastega võrreldes rohkem erinevaid õpetajatepoolse internetikasutuse vahendamise viise. Lisaks eristusid väikeasulate lapsed selle poolest, et nende õpetajad mitte ainult ei kehtesta rohkem internetikasutuse reegleid (piirav vahendamine), vaid eelkõige juhendavad, kuidas turvaliselt virtuaalmaailmas tegutseda, ning pakuvad abi negatiivsete internetikogemuste korral. Seega sekkuvad väikeste asulate õpetajad aktiivsemalt ja mitmekülgsemalt laste internetikasutusse ning on valmis võtma eri rolle (väravavaht, treener, usaldusisik), et tagada laste hõlpsam ja ohutum toimetulek küberruumis. Kuna väikeasulate kooliklassid on tavaliselt väiksemad, siis on ka õpetajatel rohkem võimalusi lastega individuaalselt tegeleda, nende internetikasutust jälgida ja neid toetada.

Tulemustest selgus, et vanuse ja internetikasutuse juhendamise vahel on positiivne seos, mis võib olla osaliselt tingitud kumulatiivsest efektist. Kuna küsimustes õpetajate vahendustegevuse kohta ei olnud täpsustatud ajavahemikku, on vanematel lastel olnud suurem tõenäosus kuulda oma koolielu jooksul pedagoogidelt mõnda internetikasutuse juhist. Lisaks võib arvata, et õpetajad, olles rohkem või vähem teadlikud sellest, et vanemad õpilased kasutavad suuremal määral interneti pakutavaid võimalusi ning puutuvad kokku enamate riskidega (Livingstone et al., 2011a), kohandavad oma vahendamisstrateegiaid vastavalt õpilaste eale.

Enamiku õpetajatepoolse vahendamise viiside puhul ei eristunud tulemused lapse soo järgi, mis võib tuleneda sellest, et õpetajate tegevus on valdavalt suunatud kogu klassile. Erinevused ilmnesid ainult kahe vahendamisviisi puhul. Nimelt olid tüdrukud poistega võrreldes saanud õpetajatelt rohkem nõu, kuidas käituda, kui neid internetis miski häirib, ning abi mõne keeruka toimingu tegemisel. Nii siinse uuringu kui ka teiste autorite uuringute tulemused (Baumgartner et al., 2010; De Graaf \& Vanwesenbeeck, 2006; Jones, Mitchell, \& Finkelhor, 2012) näitavad, et tüdrukutel on poistega võrreldes suurem risk puutuda kokku internetiohtudega ja tunda end neist häirituna. Seetõttu on ka tõenäoline, et tüdrukud pöörduvad abi saamiseks või teema käsitlemiseks sagedamini õpetajate poole kui poisid. Samuti on varasemad uuringud näidanud, et tüdrukud on (keerukate) internetitegevustega hakkamasaamisel poistega võrreldes vähem enesekindlad (Henwood, Plumeridge, \& Stepulevage, 2000) ja varmamad seda tunnistama, kasutades probleemide korral oluliselt enam kommunikatiivset strateegiat, s.t küsides kelleltki nõu (Vandoninck, d'Haenens, \& Segers, 2012).

Regressioonanalüüsi abil uurisime, kuidas on seotud õpetajatepoolne vahendamine ning 11-16aastaste laste kokkupuutumine internetiohtudega 
ja kahju kogemine. Kaasasime mudelisse demograafilised näitajad ning laste internetikasutuse kogemusi ja oskusi väljendavad tunnused. Suurem risk kogeda ühe aasta jooksul internetiohte (sh küberkiusamine, internetituttavaga silmast silma kohtumine, pornograafilise materjali nägemine ning seksuaalse sisuga sõnumite saamine) ja negatiivseid tundmusi oli paremate digitaalsete oskuste ning mitmekesisema netikasutusega lastel. Sarnasele tulemusele jõudsid ka Baumgartner jt (2010) ning Staksrud ja ta kolleegid (2013). Nooremate lastega võrreldes satuvad ohtudega enam kokku teismelised, kes kasutavad internetti sagedamini ja mitmekülgsemalt ning kelle digitaalsed oskused on paremad (Sonck, Kuiper, \& de Haan, 2012; Soo et al., 2012). Veebikeskkonnas juhtunust tundsid end enam häirituna ehk kahjustatuna tüdrukud ning vene keelt kõnelevad lapsed. Varasemad Eesti uuringud on näidanud, et vene rahvusest noored kalduvad eestlastega võrreldes kasutama internetti riskantsemalt ja puutuvad enam kokku seksuaalse ahistamisega virtuaalses ja reaalses maailmas (Salla \& Surva, 2010; Soo et al., 2012).

Meid peamiselt huvitanud tegur - õpetajatepoolne internetikasutuse sotsiaalne vahendamine - osutus oluliseks ohtudega kokkupuutumise ennustajaks ainult 14-16aastaste, eesti keelt kõnelevate ja väikesest asulast pärit laste mudelis. Seega leidis teine hüpotees osaliselt kinnitust. Positiivne mõjusuund võib viidata retroaktiivsele vahendamisele ehk olukorrale, kus lapsed pöörduvad pärast juhtunut õpetajate poole online-riskide üle arutlemiseks või nõu küsimiseks, et ennetada ohtlikke situatsioone. Kuna väikestes asulates elavate ja eesti keelt rääkivate laste seas on õpetajatepoolne internetikasutuse vahendamine enam levinud, võib oletada, et nendesse rühmadesse kuuluvad lapsed tunnetavad õpetajaid turvalise internetikasutuse autoriteetidena ning on altid nendega ohtudest vestlema ja vajaduse korral nõu küsima. Samuti võivad vanemad lapsed, kellel on olnud rohkem kokkupuuteid internetiohtudega, pidada teemat aktuaalseks ning algatada vestlusi turvalise netikasutuse teemal. Huvitava tendentsina ilmnes vene keelt rääkivate laste rühma puhul nõrk negatiivne seos õpetajatepoolse vahendamise ja ohtude kogemise vahel. Vene kodukeelega laste puhul, kelle sõnul on õpetajatepoolne turvalise internetikasutuse juhendamine võrreldes eesti keelt rääkivate laste hinnangutega harvem (vt ka TNS Emor, 2014), võib vähene, ent seda enam õpilaste tähelepanu pälviv vahendamine avaldada mõningat ohtudega kokkupuutumist ennetavat mõju.

Õpetajatepoolne vahendamistegevus ei olnud seotud internetis kahju kogemisega, mis võib tähendada seda, et õpilased siiski ei pea õpetajat negatiivsete tundmuste korral oluliseks lohutajaks või nõustajaks. See tulemus 
haakub ka Kalmuse (2012) leiuga, mille järgi üksnes 2-7\% Euroopa lastest oli pöördunud õpetaja poole, kui miski internetis neid häiris.

\section{Uuringu piirangud}

Uuringu puhul võib välja tuua neli peamist piirangut, mida tuleb tulemuste tõlgendamisel arvestada. Esiteks uurisime õpetajatepoolset internetikasutuse vahendamist ainult õpilaste vaatevinklist. Samas on varasemad uuringud näidanud, et lapsed ei ole halvad informandid internetiga seotud küsimustes. Näiteks uurisid Gentile, Nathanson, Rasmussen, Reimer ja Walsh (2012) vanemate tegevust ja laste digitaalse meedia kasutust nii vanemate kui ka laste ütluste kohaselt ning leidsid, et lastelt saadud info oli mõnevõrra parem tulemuste ennustaja kui vanematelt saadud info.

Teiseks kasutasime ankeedimahu piirangu tõttu õpetajate internetikasutuse sotsiaalse vahendamise väljaselgitamiseks ainult kaheksat tegevust. Seega ei pruugi tulemused peegeldada kõiki õpetajate tegevusi, vaid ainult neid, mis on õpilastele meelde jäänud ning mille kohta ankeedis küsiti. Järgnevates uuringutes soovitame kasutada õpetajate tegevuse hindamiseks mõõdikuid, mis kataksid suuremas ulatuses ja täpsemalt erinevaid piirava, aktiivse ja toetava vahendamise viise, ning kaasata ka õpetajate sihtrühm.

Kolmandaks ei võimalda EU Kids Online'i andmestik analüüsida, kuivõrd eristub nooremate - digiajastul hariduse omandanud - õpetajate juhendamistegevus vanema põlvkonna pedagoogide omast ning milliseid vahendaja-rolle täidavad reaal- (sh arvutiõpetuse) ja humanitaarainete oppetajad. Karaseva jt (2015) leidsid, et humanitaaraineid andvad õpetajad täidavad reaalainete õpetajatega võrreldes enam väravavahi rolli, kuid kvalitatiivsest uurimismetoodikast tingituna ei saa seda tulemust üldistada. Edaspidi soovitame ulatuslikumalt uurida ja võrrelda eri vanuses ja eri ainete õpetajate tegevust laste internetikasutuse vahendamisel.

Neljandaks mööname, et meil oli demograafiliste näitajatena võimalik kasutada ainult õpilaste kodukeelt ja elukoha asulatüüpi, kuid need ei anna üheselt tõlgendatavat teavet õppekeele ega kooli suuruse ja tüübi kohta.

\section{Kokkuvõte}

Õpetajatel kui olulistel sotsialiseerijatel on täita tähtis osa laste kompetentse, vastutustundliku ja turvalise internetikasutuse harjumuste kujundamisel. Siinses analüüsis keskenduti õpetajate praktikale laste internetikasutuse sotsiaalsel vahendamisel ning selle praktika ja internetiohtudega kokkupuute seostele. Tulemused näitasid, et suure osa Eesti 
õpilaste (87\%) hinnangul olid õpetajad vähemalt ühel viisil nende internetikasutust juhendanud, kuid õpetajad rakendavad enamasti internetikasutust piiravat ja reguleerivat tehnikat. Levinud oli ka turvalise internetikasutuse instrueerimine ehk treenerirolli täitmine, kuid õpetajate funktsioon abistaja ja nõustajana veebikeskkonnas ettetulevate häirivate probleemide korral osutus tagasihoidlikuks. Õpetajatepoolses vahendamises ilmnesid erinevused keelerühmade ja asulatüüpide kaupa. Eesti keelt rääkivate ja väikestest asulatest pärit laste õpetajad sekkusid aktiivsemalt ja mitmekülgsemalt laste internetikasutusse ning pakkusid internetiohtude korral rohkem nõuandeid ja abi kui vene keelt kõnelevate ning suuremates asulates elavate laste õpetajad. Kuna häiriv veebisisu, kontaktid võõrastega ja soovimatu seksuaalne tähelepanu võivad halvendada lapse toimetulekut ning osutuda suuremaks riskiks, kui laps seda arvab, siis on oluline suurendada eelkõige vene õppekeelega õpetajate pädevust laste internetiohtude ennetamisel ning valmisolekut sekkuda probleemsete juhtumite korral. Uurimistulemusi saab rakendada õpetajate taseme- ja täiendkoolituses.

\section{Tänusõnad}

Artikkel on valminud Haridus- ja Teadusministeeriumi institutsionaalse uurimistoetuse IUT 20-38 ja Eesti Teadusagentuuri grandi ETF 8527 toel. Artiklis on kasutatud võrgustiku EU Kids Online andmeid, mis on kogutud Euroopa Komisjoni turvalisema interneti programmi (projekt SIPKEP-321803) toetusel (vt www.eukidsonline.net).

\section{Kasutatud kirjandus}

Ainsaar, M., Soo, K., Strömpl, J., Kolpakova, O., \& Allegro, S. (2012). Adolescents' strategies for avoiding online sexual violence. Maltrattamento e abuso all'infanzia, 14(3), 53-71. Retrieved from http://www.francoangeli.it/riviste/Scheda_Rivista.asp $\mathrm{x}$ ?IDArticolo $=47448 \&$ Tipo $=$ Articolo PDF\&lingua $=$ it\&idRivista $=76$.

Baumgartner, S. E., Valkenburg, P. M., \& Peter, J. (2010). Unwanted online sexual solicitation and risky sexual online behavior across the lifespan. Journal of Applied Developmental Psychology, 31(6), 439-447. doi: http://dx.doi.org/10.1016/j.appdev.2010.07.005

Baumgartner, S. E., Valkenburg, P. M., \& Peter, J. (2011). The influence of descriptive and injunctive peer norms on adolescents' risky sexual online behavior. Cyberpsychology, Behavior, and Social Networking, 14(12), 753-758. doi: http://dx.doi.org/10.1089/cyber.2010.0510 
Berrier, T. (2007). Sixth-, seventh-, and eighth-grade students' experiences with the internet and their internet safety knowledge (Doctoral dissertation). Retrieved from http://etd-submit.etsu.edu/etd/theses/available/et.

Berson, I. R. (2003). Grooming cybervictims: The psychosocial effects of online exploitation for youth. Journal of School Violence, 2(1), 9-18. doi: http://dx.doi.org/10.1300/J202v02n01_02

Bonfadelli, H. (2007). Media education, family involvement in. In J. J. Arnett (Ed.), Encyclopedia of children, adolescents, and the media (Vol. 2, pp. 495-496). Thousand Oaks, CA: Sage Publications. doi: http://dx.doi.org/10.4135/9781412952606.n257

Buckingham, D., Banaji, S., Burn, A., Carr, D., Cranmer, S., \& Willett, R. (2005). The media literacy of children and young people: A review of the research literature on behalf of Ofcom. London: Centre for the Study of Children. Retrieved from http://stakeholders.ofcom.org.uk/binaries/research/media-literacy/ml_children.pdf.

Chakroff, J. L., \& Nathanson, A. I. (2011). Parent and school interventions: Mediation and media literacy. In S. L. Calvert \& B. J. Wilson (Eds.), The handbook of children, media, and development (pp. 552-576). Chichester: Wiley-Blackwell.

Cope, B., \& Kalantzis, M. (2000). Introduction: Multiliteracies: The beginnings of an idea. In B. Cope \& M. Kalantzis (Eds.), Multiliteracies: Literacy learning and the design of social futures (pp. 3-8). London: Psychology Press.

Davidson, J., Grove-Hills, J., Bifulco, A., Gottschalk, P., Caretti, V., Pham, T., \& Webster, S. (2011). Online abuse: Literature review and policy context. European Commission Safer Internet Plus Programme. Retrieved from http://www.europeanonlinegroomingproject.com/media/2080/eogp-literature-review.pdf.

De Graaf, H., \& Vanwesenbeeck, I. (2006). „Seks is een game”. Gewenste en ongewenste seksuele ervaringen van jongeren op internet. Utrecht: Rutgers Nisso Groep.

Dürager, A., \& Livingstone, S. (2012). How can parents support children's internet safety? London: London School of Economics \& Political Science, EU Kids Online. Retrieved from http://eprints.lse.ac.uk/42872/.

Freedom House (2014). Freedom on the Net 2014: Graphics. Retrieved from https://freedomhouse.org/report/freedom-net-2014/freedom-net-2014-graphics\#. VNZlsVORSy0.

Gentile, D. A., Nathanson, A. I., Rasmussen, E. E., Reimer, R. A., \& Walsh, D. A. (2012). Do you see what I see? Parent and child reports of parental monitoring of media. Family Relations, 61(3), 470-487. doi: http://dx.doi.org/10.1111/j.1741-3729.2012.00709.x

Hasebrink, U., Livingstone, S., \& Haddon, L. (2008). Comparing children's online opportunities and risks across Europe: Cross-national comparisons for EU Kids Online. London: EU Kids Online. Retrieved from http://eprints.lse.ac.uk/21656/.

Helweg-Larsen, K., Schütt, N., \& Larsen, H. B. (2012). Predictors and protective factors for adolescent internet victimization: Results from a 2008 nationwide Danish youth survey. Acta Paediatrica, 101(5), 533-539.

doi: http://dx.doi.org/10.1111/j.1651-2227.2011.02587.x

Henwood, F., Plumeridge, S., \& Stepulevage, L. (2000). A tale of two cultures? Gender and inequality in computer education. In S. Wyatt, F. Henwood, N. Miller, \& P. Senker (Eds.), Technology and in/equality: Questioning the information society (pp. 111-128). London, New York: Routledge. 
Jones, L. M., Mitchell, K. J., \& Finkelhor, D. (2012). Trends in youth internet victimization: Findings from three youth internet safety surveys 2000-2010. Journal of Adolescent Health, 50(2), 179-186. doi: http://dx.doi.org/10.1016/j.jadohealth.2011.09.015

Kalmus, V. (2012). Making sense of the social mediation of children's internet use: Perspectives for interdisciplinary and cross-cultural research. In C. W. Wijnen, S. Trültzsch, \& C. Ortner (Eds.), Medienwelten im Wandel: Kommunikationswissenschaftliche Positionen, Perspektiven und Konsequenzen. Festschrift für Ingrid Paus-Hasebrink [Changing media worlds: Positions, perspectives and consequences in communication science. Festschrift in honour of Ingrid Paus-Hasebrink] (pp. 137-149). Wien: Springer VS.

Kalmus, V. (2013). Laste turvalisus uues meediakeskkonnas. M. Heidmets (toim.), Eesti inimarengu aruanne 2012/2013: Eesti maailmas (lk 83-85). Tallinn: Eesti Koostöö Kogu. Külastatud aadressil http://www.kogu.ee/wp-content/uploads/2013/05/EIA20122013.pdf.

Kalmus, V., Pruulmann-Vengerfeldt, P., Runnel, P., \& Siibak, A. (2009). Online content creation practices of Estonian schoolchildren in a comparative perspective. Journal of Children and Media, 3(4), 331-348. doi: http://dx.doi.org/10.1080/17482790903233333

Kalmus, V., \& Roosalu, T. (2012). Institutional filters on children's internet use: An additional explanation of cross-national differences in parental mediation. In M. Walrave, W. Heirman, S. Mels, C. Timmerman, \& H. Vandebosch (Eds.), eYouth: Balancing between opportunities and risks (pp. 235-250). Brussels: Peter Lang.

Kalmus, V., Siibak, A., \& Blinka, L. (2014). Internet and child well-being. In A. BenArieh, I. Frones, F. Casas, \& J. E. Korbin (Eds.), Handbook of child well-being: Theories, methods and policies in global perspective (pp. 2093-2133). Dordrecht: Springer. doi: http://dx.doi.org/10.1007/978-90-481-9063-8_75

Kalmus, V., von Feilitzen, C., \& Siibak, A. (2012). Effectiveness of teachers' and peers' mediation in supporting opportunities and reducing risks online. In S. Livingstone, L. Haddon, \& A. Görzig (Eds.), Children, risk and safety on the internet: Research and policy challenges in comparative perspective (pp. 245-256). Bristol: The Policy Press. doi: http://dx.doi.org/10.1332/policypress/9781847428837.003.0019

Kanuga, M., \& Rosenfeld, W. D. (2004). Adolescent sexuality and the internet: The good, the bad, and the URL. Journal of Pediatric and Adolescent Gynecology, 17(2), 117-124. doi: http://dx.doi.org/10.1016/j.jpag.2004.01.015

Karaseva, A., Siibak, A., \& Pruulmann-Vengerfeldt, P. (2015). Relationships between teachers' pedagogical beliefs, subject cultures, and mediation practices of students' use of digital technology. Cyberpsychology: Journal of Psychosocial Research on Cyberspace, 9(1). Retrieved from http://cyberpsychology.eu/view. php?cisloclanku=2015051403. doi: http://dx.doi.org/10.5817/CP2015-1-6

Kirwil, L., Garmendia, M., Garitaonandia, C., \& Martínez Fernández, G. (2009). Parental mediation. In S. Livingstone \& L. Haddon (Eds.), Kids online: Opportunities and risks for children (pp. 199-215). Bristol: The Policy Press. doi: http://dx.doi.org/10.1332/policypress/9781847424396.003.0016 
Komp, L. (2012). Oluliste teiste roll 3. klassi laste toimetulemisel online-riskidega (magistritöö). Külastatud aadressil http://hdl.handle.net/10062/25781.

Leu, D. J., O’Byrne, W. J., Zawilinski, L., McVerry, J. G., \& Everett-Cacopardo, H. (2009). Comments on Greenhow, Robelia, and Hughes: Expanding the new literacies conversation. Educational Researcher, 38(4), 264-269. doi: http://dx.doi.org/10.3102/0013189X09336676

Livingstone, S. (2004). Media literacy and the challenge of new information and communication technologies. The Communication Review, 7(1), 3-14. doi: http://dx.doi.org/10.1080/10714420490280152

Livingstone, S., \& Bober, M. (2004). UK children go online: Surveying the experiences of young people and their parents. London: LSE Research Online. Retrieved from http://eprints.lse.ac.uk/395/1/UKCGOsurveyreport.pdf.

Livingstone, S., Haddon, L., Görzig, A., \& Ólafsson, K. (2011a). Risks and safety on the internet: The perspective of European children. Full findings. LSE, London: EU Kids Online. Retrieved from http://eprints.lse.ac.uk/33731/

Livingstone, S., Haddon, L., Görzig, A., \& Ólafsson, K. (2011b). Technical report and user guide: The 2010 EU Kids Online Survey. LSE, London: EU Kids Online. Retrieved from http://eprints.lse.ac.uk/45270/

Livingstone, S., \& Helsper, E. J. (2007). Taking risks when communicating on the internet: The role of offline social-psychological factors in young people's vulnerability to online risks. Information, Communication \& Society, 10(5), 619643. doi: http://dx.doi.org/10.1080/13691180701657998

Livingstone, S., \& Helsper, E. (2008). Parental mediation of children's internet use. Journal of Broadcasting \& Electronic Media, 52(4), 581-599. doi: http://dx.doi.org/10.1080/08838150802437396

Livingstone, S., \& Smith, P. K. (2014). Annual research review: Harms experienced by child users of online and mobile technologies: The nature, prevalence and management of sexual and aggressive risks in the digital age. Journal of Child Psychology and Psychiatry, 55(6), 635-654. doi: http://dx.doi.org/10.1111/jcpp.12197

McQuail, D. (2005). McQuaili massikommunikatsiooni teooria. Tartu: Tartu Ülikooli Kirjastus.

Mitchell, K. J., Finkelhor, D., \& Wolak, J. (2001). Risk factors for and impact of online sexual solicitation of youth. Journal of the American Medical Association, 285(23), 1-4. doi: http://dx.doi.org/10.1001/jama.285.23.3011

Mitchell, K. J., Finkelhor, D., \& Wolak, J. (2007). Youth internet users at risk for the most serious online sexual solicitations. American Journal of Preventive Medicine, 32(6), 532-537. doi: http://dx.doi.org/10.1016/j.amepre.2007.02.001

Munro, E. R. (2011). The protection of children online: A brief scoping review to identify vulnerable groups. Childhood Wellbeing Research Centre. Retrieved from http://www.saferinternet.org.uk/content/childnet/safterinternetcentre/downloads/ Research_Highlights/Munro_OnlinevulnerabilityReporttoDFE-Final-October2011.pdf.

O’Connel, R., Price, J., \& Barrow, C. (2004). Emerging trends amongst primary school children's use of the internet. Preston: University of Central Lancashire, Cyberspace Research Unit. 
Pruulmann-Vengerfeldt, P., Roots, A., Strenze, T., \& Ainsaar, M. (2015). Tehnoloogiarikkas keskkonnas probleemilahendusoskus ja IKT kasutus: PIAAC uuringu temaatiline aruanne $n \mathrm{r}$ 4. Tartu: Haridus- ja Teadusministeerium.

Quayle, E., Hutton, L., \& McKenzie, K. (2012). Research results across different groups of young people. In O. Kolpakova (Ed.), Online behaviour related to child sexual abuse: Focus groups' findings (pp. 40-101). Stockholm: Counsil of the Baltic Sea states, ROBERT project.

Raudsik, I. (2012). Õpetajad ja eakaaslased internetikasutuse vahendajatena põhikooli ópilaste pilgu läbi (bakalaureusetöö). Külastatud aadressil http://dspace.utlib.ee/ dspace/bitstream/handle/10062/25859/raudsik_iris.pdf?sequence=1.

Salla, J., \& Surva, L. (2010). Vägivald ja ohvrid. J. Salla (toim.), Kuriteoohvrite uuring 2009. Kriminaalpoliitika uuringud 14 (lk 40-52). Tallinn: Justiitsministeerium. Külastatud aadressil http://www.kriminaalpoliitika.ee/sites/www.kriminaalpoliitika.ee/files/elfinder/dokumendid/14._kuriteoohvrite_uuring_2009.pdf.

Siibak, A., \& Hernwall, P. (2011). 'Looking like my favourite Barbie' - Online gender construction of tween girls in Estonia and in Sweden. Studies of Transition States and Societies, 3(2), 57-68.

Sonck, N., Kuiper, E., \& de Haan, J. (2012). Digital skills in the context of media literacy. In S. Livingstone, L. Haddon, \& A. Görzig (Eds.), Children, risk and safety on the internet: Research and policy challenges in comparative perspective (pp. 87-98). Bristol: The Policy Press.

doi: http://dx.doi.org/10.1332/policypress/9781847428837.003.0007

Soo, K., Ainsaar, M., \& Kalmus, V. (2012). Behind the curtains of e-state: Determinants of online sexual harassment among Estonian children. Studies of Transition States and Societies, 4(2), 35-48. Retrieved from http://publications.tlu.ee/index.php/stss/article/view/95/85.

Subrahmanyam, K., \& Greenfield, P. (2008). Online communication and adolescent relationships. The Future of Children, 18(1), 119-146. doi: http://dx.doi.org/10.1353/foc.0.0006

Staksrud, E., Ólafsson, K., \& Livingstone, S. (2013). Does the use of social networking sites increase children's risk of harm? Computers in Human Behavior, 29(1), 40-50. doi: http://dx.doi.org/10.1016/j.chb.2012.05.026

Zhao, L., Lu, Y., Wang, B., \& Huang, W. (2011). What makes them happy and curious online? An empirical study on high school students' internet use from a selfdetermination theory perspective. Computers \& Education, 56(2), 346-356. doi: http://dx.doi.org/10.1016/j.compedu.2010.08.006

TNS Emor (2014). Riskikäitumise teadlikkuse uuring kolmes sihtrühmas. Uuringu raport. Tallinn: TNS Emor. Külastatud aadressil https://www.politsei.ee/dotAsset/331164.pdf.

Uljens, M. (1997). School didactics and learning: A school didactic model framing an analysis of pedagogical implications of learning theory. Hove: Psychology Press.

Valkenburg, P. M., \& Peter, J. (2007). Internet communication and its relation to well-being: Identifying some underlying mechanisms. Media Psychology, 9(1), 43-58. doi: http://dx.doi.org/10.1080/15213260709336802

Vandoninck, S., d'Haenens, L., \& Segers, K. (2012). Coping and resilience: Children's responses to online risks. In S. Livingstone, L. Haddon, \& A. Görzig 
(Eds.), Children, risk and safety online: Research and policy challenges in comparative perspective (pp. 205-218). Bristol: The Policy Press.

doi: http://dx.doi.org/10.1332/policypress/9781847428837.003.0016

Vinter, K. (2013). Digitaalse ekraanimeedia tarbimine 5-7-aastaste laste seas ja selle sotsiaalne vahendamine Eestis. Pedagoogiline vaatekoht (doktoritöö). Külastatud aadressil http://e-ait.tlulib.ee/318/1/vinter_kristi.pdf.

Vinter, K., \& Siibak, A. (2012). The role of parents in guiding pre-school children's use of computers and the internet: Analyzing perceptions of Estonian children and parents. In J. Mikk, M. Veisson, \& P. Luik (Eds.), Lifelong learning and teacher development. Estonian studies in education (Vol. 4, pp. 78-94). Frankfurt am Main etc.: Peter Lang.

Wishart, J. (2004). Internet safety in emerging educational contexts. Computers \& Education, 43(1/2), 193-204. Retrieved from http://www.researchgate.net/profile/Jocelyn_Wishart/publication/220140831_Internet_safety_in_emerging_ educational_contexts/links/0912f50f330a541d9b000000.pdf. doi: http://dx.doi.org/10.1016/j.compedu.2003.12.013

Wolak, J., Finkelhor, D., Mitchell, K. J., \& Ybarra, M. L. (2008). Online „predators” and their victims: Myths, realities, and implications for prevention and treatment. American Psychologist, 63(2), 111-128. Retrieved from http://www.apa.org/pubs/journals/releases/amp-632111.pdf. doi: http://dx.doi.org/10.1037/0003-066X.63.2.111

Wolak, J., Mitchell, K. J., \& Finkelhor, D. (2003). Escaping or connecting? Characteristics of youth who form close online relationships. Journal of Adolescence, 26(1), 105-119. doi: http://dx.doi.org/10.1016/S0140-1971(02)00114-8

Wolak, J., Mitchell, K. J., \& Finkelhor, D. (2006). Online victimization of youth: Five years later. National Center for Missing \& Exploited Children. Retrieved from http://www.unh.edu/ccrc/pdf/CV138.pdf. 


\title{
The role of Estonian teachers in the social mediation of children's internet use
}

\author{
Kadri Soo $^{\text {a1 }}$, Veronika Kalmus ${ }^{\text {a }}$, Mare Ainsaar ${ }^{\mathrm{a}}$ \\ ${ }^{a}$ University of Tartu, Institute of Social Science
}

\section{Summary}

This article investigates the socio-demographic differences of Estonian teachers' social mediation of 9-16 old children's internet use. The social mediation of children's internet use refers to practice and strategies employed by socialising agents to support, monitor and regulate children's online activities (Kalmus, 2012). Social mediation embraces socially supportive practices, such as guidance, co-use and co-interpreting, but it also consists of setting rules and restrictions.

Children and parents believe that it is the responsibility of teachers to educate children about safer and better online behaviour (Ainsaar et al., 2012; O'Connel et al., 2004; Wishart, 2004). At the same time our knowledge about teachers' role as social mediators of internet use is limited. More information is also needed about possible differences in the social mediation of internet use in different regions (urban/rural areas) and language groups. Previous studies have mainly concentrated on parental mediation activities (Dürager \& Livingstone, 2012; Kalmus \& Roosalu, 2012; Livingstone \& Helsper, 2008) and the role of teachers has been partly neglected (Kalmus et al., 2012). Kalmus et al. (2012) analysed the EU Kids Online data in all European countries and found evidence that teachers' social mediation activities are positively related with students' digital literacy and safety skills. They also argue that the main role of teachers in most European countries is the role of web coaches.

Although guidance and help from adults might help children to avoid or mitigate online risks (Dürager \& Livingstone, 2012), previous research results have been controversial. For example, analysis by Kalmus et al. (2012) showed that children's perception of online risks and harm is positively associated with more support from teachers and peers. This result is quite surprising, but might be explained by hypothesising that the help

1 Institute of Social Science, Faculty of Social Science and Education, University of Tartu, Lossi 36, 51003 Tartu, Estonia; kadri.soo@ut.ee 
of teachers is used retroactively, after children have had a negative online experience.

The aim of the article is to give an overview on the social mediation practices of Estonian teachers in different municipality types and language groups. Besides that, the influence of teachers' social mediation on children's online risk behaviour and harm experience is examined. We investigate the Internet use in Estonia because Estonia is a country with one of the highest internet freedom levels in the world (Freedom House, 2014). Recent representative surveys (Livingstone et al., 2011a; Kalmus, 2013) demonstrate that Estonian children are active internet users with a high level of risky online activities, while the level of parental mediation is quite low, and parents rely on teachers and older siblings as mediators of children's internet use (Komp, 2012; Vinter \& Siibak, 2012).

We use data on Estonian children from the international EU Kids Online survey (see Livingstone et al., 2011b). The survey was conducted as a computer assisted personal interview with a response rate of $78 \%$ among 9-16 year-old children. A random stratified sample of 1005 children who used the internet was collected in 2010; 51\% of them were boys and 49\% girls. Most of the children (81\%) gave Estonian as their home language, 19\% spoke Russian. Children (1\%) who reported both Estonian and Russian as spoken at home were classified among Estonian speaking children in the analysis. The age distribution was as follows: $22.0 \%$ 9-10 years old, $23.1 \% 11-12$ years old, $26.4 \% 13-14$ years old, and $28.5 \% 15-16$ years old. Nearly one quarter (24\%) of children lived in cities with more than 100,000 inhabitants, $29 \%$ in towns with $10,000-100,000$ inhabitants and $46.4 \%$ in smaller towns and rural settings.

We measured teachers' social mediation of internet use with eight activities: making rules about what a child can do on the internet at school (restrictive mediation); talking with a child about what they do on the internet (active mediation of internet use); helping a child when something is difficult to do or find on the internet; explaining why some websites are good or bad; suggesting ways to use the internet safely; suggesting ways to behave towards other people online; talking to a child about what to do if something on the internet bothers the child; having helped a child in the past when something had bothered the child on the internet (active mediation of internet safety). All activities were recorded as children's reports about teachers' activities. We used an index of the social mediation of internet use, computed as the sum of teachers' different activities.

In addition, we used different indexes to measure children's online experiences: 
- The index of children's risky online experiences was constructed, based on self-reported experiences on the internet within the last 12 months concerning: (1) receiving or seeing sexual messages, (2) experience of hurtful or nasty behaviour (cyberbullying), (3) seeing sexual content, (4) meeting online contacts offline (47\% of 11-16 year-old children had experienced at least one online risk);

- Experience of harm on the internet was measured using two categories: 1 - no experience of any risky situation or harm; 2 - experience of harm from receiving or seeing sexual messages, seeing sexual content, or meeting online contacts offline ( $17 \%$ of children reported about harm from online risks);

- Digital skills is the sum index of eight digital literacy and safety skills (for example, changing privacy settings on a social networking profile; blocking messages from someone a child does not want to hear from; etc.);

- The range of internet activities sums up 16 different online activities practiced with a frequency of at least once a week.

Majority (87\%) of Estonian children aged 9-16 reported about some activities of teachers' social mediation of the internet. The most common type of the social mediation of the internet was restrictive mediation, while active mediation of internet safety was also quite common among Estonian teachers.

Teachers in smaller municipalities and the Estonian-speaking community were most active in mediating children's internet use. They also used the most diverse range of different mediation activities. A possible explanation may be that teachers in smaller municipality schools have smaller classes and, thus, more personal contacts with students.

There were no gender differences in the case of most of the social mediation types, probably because teachers' activities are targeted at the whole class, and there are predominantly mixed gender classes in Estonia. Two exceptions were revealed: more girls reported about being helped by a teacher when something was difficult to do or find on the internet, and when something on the internet bothered them. The gender differences can be a result of the higher exposure of girls to online risks and harm (Baumgartner et al., 2010; De Graaf \& Vanwesenbeeck, 2006; Jones et al., 2012), their lower self-confidence in digital skills (Henwood et al., 2000), and greater readiness to ask for help (Vandoninck et al., 2012).

We analysed the relationships between teachers' social mediation of the internet use and children's risky online experiences in different age groups, language groups and municipality types, taking into account the range of 
internet activities and digital skills. It turned out that children with better digital skills also experienced more online risks. Teachers' social mediation was not a statistically significant predictor in the whole sample, but in the sub-samples of 14-16 year olds, Estonian-speaking children and those living in small municipalities a positive correlation existed. The more attention teachers paid to internet issues, the more students had risky online experiences. We explain this by retroactive mediation: children having experienced more risks also speak more about those issues with a teacher either on their own initiative or on the initiative of a teacher. Teachers' social mediation of internet use did not have any influence on children's perception of online harm.

Keywords: social mediation of internet use, teacher's role, online risks, online harm, digital skills 